\title{
Histomorphometric Changes of The Parietal Cell of The Stomach with Age - A Postmortem Study
}

\author{
Gul Newaz Begum ${ }^{1}$, Abu Sadat Mohammad Nurunnabi ${ }^{2}$, Sunjida Shahriah ${ }^{3}$, Khandaker Abu \\ Rayhan $^{4}$, Mahamuda Begum ${ }^{5}$
}

\begin{abstract}
Background: The quantity of acid produced by the stomach correlates with the functional capability and number of parietal cell mass. Researchers have found that the number of parietal cells tends to increase with advancing age in different population-based studies. Objective: A cross-sectional descriptive type of study was designed to see the variation in the number and diameter of the parietal cells of the stomach with advancing age in Bangladeshi people. Methods: The present study was done in the Department of Anatomy, Dhaka Medical College, Dhaka, from July 2005 to June 2006, based on collection of 60 human stomachs from the unclaimed dead bodies that were under examination in the morgue of Dhaka Medical College, Dhaka. The samples were divided into three age-groups including group A (2-16 years), group B (17-22 years) and group C (23-65 years). A total of 8 relatively fresh samples from group A, 8 from group B and 14 from group $\mathrm{C}$ were selected for histological study. Then best prepared histological slides from each group were taken and examined under the light compound microscope to determine the number per sq. $\mathrm{mm}$ and average diameter of the parietal cells by using the ocular micrometer. Results: The number of parietal cells per square $\mathrm{mm}$ of microscopic fields were found $1197.88 \pm 73.34$ in group A, $1362.25 \pm 55.67$ in group B and $1615.57 \pm 123.57$ in group C. The difference between group A \& B, B \& C and A \& C were statistically significant. The average diameter of the parietal cells were found $14.44 \pm 1.58 \mathrm{ìm}, 16.87 \pm 0.48 \mathrm{ìm}, 17.67 \pm 1.28 \mathrm{ìm}$ in group $\mathrm{A}, \mathrm{B}$ and $\mathrm{C}$ respectively. The difference between group $A \& B$ and $A \& C$ were statistically significant. Conclusion: The number of the parietal cells increases with age, even in old age. However, the diameter of the parietal cell increases up to the $3^{\text {rd }}$ decade of life and then remains static.
\end{abstract}

Key words: Stomach, histology, gastric gland, parietal cell.

Bangladesh Soc Physiol. 2013, December; 8(2): 89-93

For Authors Affiliation, see end of text.

http://www.banglajol.info/index.php/JBSP

\section{Introduction}

$\mathbf{T}$ he best known component of gastric juice is hydrochloric acid, which is the secretory product of the parietal cells. ${ }^{1}$

The parietal cells are distributed along the length of the gastric glands, but tend to be numerous in the isthmus of the glands. ${ }^{2-4}$ These cells are recognized by their copious eosinophilic

Received February 2013; Accepted August 2013 cytoplasm and central nuclei. ${ }^{5,6}$ They are large, rounded and triangular cells. ${ }^{5-7}$ It is known that the capacity of the stomach to secrete hydrochloric acid is almost linearily related to parietal cell numbers. ${ }^{8}{ }^{9}$ From the end of the first trimester, parietal cells are present in a mature, functional form in the gastric mucosa with the potential to secrete gastric acid. ${ }^{10}$ A normal human stomach contains approximately one 
billion parietal cells, which are capable of producing and concentrating hydrochloric acid ${ }^{8}$. The quantity of acid produced by the stomach correlates with the functional capability and number of parietal cell mass. ${ }^{10,11}$ It is also evident that the patients of chronic gastritis and peptic ulcer generally have a larger parietal cell mass than that of normal persons. ${ }^{10}$ Moreover, researchers have found that the number of parietal cells tends to increase with advancing age in different population-based studies. ${ }^{10-13}$ Analysis of the normal production and loss of parietal cells provides the basis for understanding the pathogenesis of several diseases that affect parietal cell mass (e.g. Zollinger-Ellison syndrome and chronic atrophic gastritis). ${ }^{14}$ Therefore, the aim of the present study was to find out the histomorphomtric changes, i.e. number and size, of the parietal cells in a Bangladeshi population and compare with the previous studies. The results of the present study can be used as a standard reference for the morphometry of gastric glands and to correlate the abnormality in functional capacity in pathological cases.

\section{Methods}

Collection of Sample: A cross-sectional descriptive study was carried out in the Department of Anatomy, Dhaka Medical College, Dhaka, from July 2005 to June 2006, based on the postmortem collection of human stomach. The samples of human stomach were collected from the unclaimed dead bodies that were under examination in the morgue of Dhaka Medical College, Dhaka. The present study was approved by the Ethical Review Committee of Dhaka Medical College, Dhaka.

All the samples were collected within 24-36 hours of death without any sign of putrefaction and taken from medicolegal cases excluding poisoning, any cutting or crushing injury to stomach, and viscera having grossly abnormal size. During collection appropriate age, sex and cause of death were noted from morgue's record book. The samples were tagged immediately, which was bearing a code number for subsequent identification. Soon after collection, each sample was gently washed in tap water on a dissection tray. Blood and blood clots were removed as far as possible. Omenta, fat and other unwanted tissues were removed. Then the samples were fixed in $10 \%$ formol saline solution. After isolation, the samples were divided into three age-groups i.e. group A (2-16 years), group B (1722 years), and group $\mathrm{C}$ (23-65 years), according to Farinati et al. ${ }^{5}$

Preparation of histological slides: The stomach was fixed in $10 \%$ formol saline in a plastic container. A total of 8 relatively fresh samples from group A, 8 from group B and 14 from group $\mathrm{C}$ were selected for histological study. A sharp knife was placed on the stomach, and it was cut sharply to obtain a slice of tissue having $3 \mathrm{~mm}$ in thickness. Each of the samples was fixed with $10 \%$ formol saline for 24 hours. Then the tissues were washed in running tap water, dehydration was done with ascending grades of alcohol, cleared with xylene, infiltrated and embedded in paraffin. Paraffin blocks were cut at $5 \mathrm{~mm}$ thickness and were stained with routine Harris' Haematoxylin and Eosin (H \& E) stain. Only best prepared slides from each of the tissue blocks was chosen for the study.

Estimation of the number of the parietal cells per sq. mm area of the microscopic field: The light compound microscope which was used for the microscopic measurement was OLYMPUS CHB, made in Tokyo, Japan. According to Enayetullah $^{12}$, the stained tissue section on the slide (' 40 objective,' 10 eyepiece) was divided into three equal parts by a computer generated, photographically produced equal sized room over a transparent plastic sheet by drawing three lines which radiated from the centre towards the periphery at 10 o'clock, 2 o'clock and 6 o'clock position. Then, this sheet was fixed on the top of the cover slip by adhesive tape. The centre of this sheet corresponded with the centre of the tissue section. From each triangular area, one microscopic field was selected near the centre for study. Thus from each slide, three different fields were chosen for counting the number parietal cells. Therefore, a total of 45 fields were taken for the study. A counting circle of $5 \mathrm{~mm}$ diameter was printed on a transparent plastic sheet, which was cut to fit into the eyepiece of the light microscope. Thus a black circular outline was 
superimposed over the actual microscopic field. The parietal cells are large, rounded and triangular with eosinophilic cytoplasm and central nuclei (Figure 1). The circle encircled some total of the parietal cells, while some other parietal cells were partly included inside that circle. However, the rest of the parietal cells were also seen. Considering this circle as the field to be studied (rather than the whole microscopic field), the portions of the parietal cells inside this field were taken in consideration by an eye estimate e.g. 1, 0.75, 0.5, 0.25 etc. From the three counts of three different fields of each slide, an average count was calculated for each slide. Thus, the average counts of the slides for each species were available. The count was then converted into number per square $\mathrm{mm}$ by conversion measurement of an ocular micrometer and a stage micrometer. ${ }^{15}$

Measurement of the diameter of the parietal cells of the stomach: The parietal cells of the stomach were triangular rather than rounded (Figure 1), which was somewhat difficult in measuring the actual diameter. To overcome such type of drawback, the numbers of ocular micrometer divisions were read out from near to remote margins of the parietal cells and measurements were taken twice for parietal cell i.e. maximum transverse diameter and another perpendicular to it. Then the numbers of micrometer divisions were multiplied by the correlation factor derived earlier keeping the magnification constant (' 40

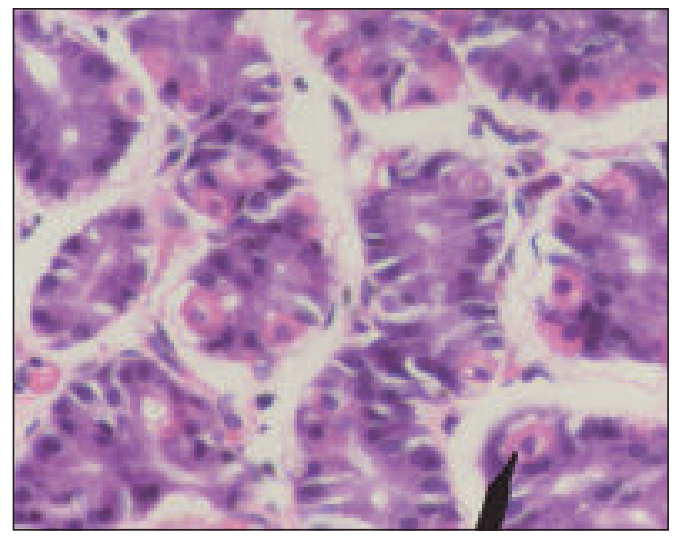

Figure 1. Photomicrograph of parietal cell of the stomach taken from group $B$ (17-22 years) ('40 objectives, '10 eyepiece) ( $H \&$ E stain). objective,' 10 eyepiece). Therefore, the diameter of parietal cell was calculated as follows:

Diameter of parietal cell $=($ Maximum transverse diameter + Maximum perpendicular diameter $) \div 2$

Then the average diameter was calculated in ìm by conversion measurement of an ocular micrometer and a stage micrometer ${ }^{15}$.

The data collected from the histological studies were processed and statistical analyses were done by one-way ANOVA test, using the SPSS 11.0 version.

\section{Results}

The number of the parietal cells per square mm of microscopic field were $1197.88 \pm 73.34$ in group A, $1362.25 \pm 55.67$ in group $B$ and $1615.57 \pm 123.57$ in group $\mathrm{C}$. The difference between group A vs B, B vs $\mathrm{C}$ and $\mathrm{A}$ vs $\mathrm{C}$ were statistically significant (Table I). The average diameter of the parietal cells were found $14.44 \pm 1.58 \mathrm{im}, 16.87 \pm 0.48 \mathrm{im}$, $17.67 \pm 1.28 \mathrm{im}$ in group $\mathrm{A}, \mathrm{B}$ and $\mathrm{C}$ respectively. The difference between group A \& B and A \& C were statistically significant (Table I).

Table I: Number and diameter of parietal cells in different study groups

\begin{tabular}{lcc}
\hline Group & $\begin{array}{c}\text { Number/sq. mm } \\
\text { Mean } \pm \text { SD }\end{array}$ & $\begin{array}{c}\text { Diameter(in ìm) } \\
\text { Mean } \pm \text { SD }\end{array}$ \\
\hline A & $1197.88 \pm 73.34$ & $14.44 \pm 1.58$ \\
$(\mathrm{n}=8)$ & $(1042-1293)$ & $(11.34-16.26)$ \\
$\mathrm{B}$ & $1362.25 \pm 55.67$ & $16.87 \pm 0.48$ \\
$(\mathrm{n}=8)$ & $(1300-1462)$ & $(16.28-17.68)$ \\
$\mathrm{C}$ & $1615.57 \pm 123.57$ & $17.67 \pm 1.28$ \\
$(\mathrm{n}=14)$ & $(1503-1865)$ & $(15.98-19.58)$ \\
\hline & \multicolumn{2}{c}{$\mathrm{P}$ value } \\
A vs B & $<0.01^{* *}$ & $<0.001^{* * *}$ \\
A vs C & $<0.001^{* * *}$ & $<0.001^{* * *}$ \\
B vs C & $<0.001^{* * *}$ & $>0.01^{\mathrm{ns}}$ \\
\hline
\end{tabular}

Figures in parentheses indicate range. Statistical analyses were done by ANOVA (multiple comparison), ns $=$ not significant, $* * / * * *=$ significant.Group A : 216 years;Group B : 17-22 years

Group C : 23-65 years 


\section{Discussion}

Farinati et al. ${ }^{5}$ found that the number of the parietal cells tends to increase with age. Naik et al. ${ }^{10}$ found that the average parietal cell mass in human stomach $1005.12 \pm 445.34$ million (with a range from 539.4 to 1981.9 million) in adult. Helander et al. ${ }^{16}$ estimated that in gastric mucosal tissue sections, the parietal cell number comprises of all epithelial cells $12 \%$ in humans. Mercer \& Robinson ${ }^{17}$ reported that biopsy specimens taken from the stomach have demonstrated that parietal cells account for 13\% of epithelial cells of its mucosa. Kelly et al. ${ }^{8}$ and Kumar et al. ${ }^{18}$ stated that the normal human stomach contains approximately 1 billion parietal cells. Kopic et al. ${ }^{19}$ stated that the parietal cells are found in high abundance in the gastric gland, with typically 70-90 parietal cells per gland. The findings of the present study are more or less similar to that of Farinati et al. ${ }^{5}$, Kopic et al. ${ }^{19}$. However, percentage volume of parietal cells in gastric glands was not determined in the present study.

Ito $^{20}$ stated that the most conspicuous cells of the gastric mucosa are the parietal cells and their average diameter is up to $25 \mathrm{im}$. Rohrer et al. ${ }^{21}$ found that human parietal cells are larger cells with an average diameter of 16-22ìm. Gartner \& Hiat $^{22}$ reported that they are about 20 to $25 \mathrm{im}$ in diameter. The findings of the present study are similar to Rohrer et al. ${ }^{21}$, but lower than that of Ito $^{20}$ and Gartner \& Hiatt. ${ }^{22}$ The difference may attribute to racial variation and measurement procedure. To the best of our knowledge, it was the first ever study on microscopic anatomy of parietal cell of the stomach in our country. Hence, no local data were found to compare with our study.

\section{Conclusion}

The number of the parietal cells increases with age, even in old age. However, the diameter of the parietal cell increases up to the $3^{\text {rd }}$ decade of life and then remains static. Further studies are recommended to determine the percentage volume of parietal cells in gastric glands and physiological changes with secretions of local hormones and other biochemical modulators.

\section{Authors affiliations}

1. Dr. Gul Newaz Begum, Associate Professor, Department of Anatomy, Anwer Khan Modern Medical College, Dhaka.

2. *Dr. Abu Sadat Mohammad Nurunnabi, Lecturer, Department of Anatomy, Dhaka Medical College, Dhaka. Cell Phone: +8801712290608 , Email: shekhor19@yahoo.com

3. Dr. Sunjida Shahriah, Associate Professor, Department of Anatomy, Z.H. Sikder Women's Medical College, Dhaka.

4. Dr. Khandaker Abu Rayhan, Associate Professor, Department of Anatomy, Popular Medical College, Dhaka.

5. Dr. Mahamuda Begum, Associate Professor, Department of Anatomy, Ad-Din Women's Medical College, Dhaka.

* For correspondence

\section{References}

1. Helander HF. Physiology and pharmacology of the parietal cell. Baillieres Clin Gastroenterol 1988; 2(3): 539-54.

2. Berger EH. The distribution of the parietal cells in the stomach: a histophotographic study. Am J Anat 1934; 54: 87-114.

3. Tominaga K. Distribution of parietal cells in the antral mucosa of human stomachs. Gastroenterology 1975; 69(6): 1201-7.

4. Owen DA. Normal histology of the stomach. Am J Surg Pathol 1986; 10(1): 48-61.

5. Farinati F, Formentini S, Della Libera G, Valiante F, Fanton MC, Di Mario F, et al. Changes in parietal and mucous cell mass in the gastric mucosa of normal subjects with age: a morphometric study. Gerontology 1993; 39(3): 146-51.

6. Ross MH, Pawlina W. Histology: a text and atlas with correlated cell and molecular biology. $5^{\text {th }}$ ed. Philadelphia: Lippincott Williams \& Wilkins; 2006: p. 528 .

7. Fawcett DW, Jensh RP, eds. Bloom \& Fawcett: concise histology. $1^{\text {st }}$ ed. New York: Chapman \& Hall; 1997: p.197.

8. Kelly EJ, Lagopoulos M, Primrose JN. Immunocytochemical localisation of parietal cells and $\mathrm{G}$ cells in the developing human stomach. Gut 1993; 34(8): 1057-9. 
9. Tongen LA. The quantitative relationship between parietal cells and gastric acidity. Surgery 1950; 28(6): 1009-15

10. Naik SR, Bajaj SC, Goyal RK, Gupta DN, Chuttani HK. Parietal cell mass in healthy human stomach. Gastroenterology 1971; 61(5): 682-5.

11. Perasso A, Testino G, de Angelis P, Augeri C, de Grandi R. Gastric chief cell mass in chronic gastritis: count and relationships to parietal cell mass and functional indices. Hepatogastroenterology 1991; 38(Suppl 1): 63-6.

12. Rubio CA, Nesi G. Qualitative and quantitative alterations in the parietal cell domain in chronic gastritis. Virchows Arch 2011; 458(6): 733-9.

13. Yao X, Forte JG. Cell biology of acid secretion by the parietal cell. Annu Rev Physiol 2003; 65: 103-31.

14. Karam SM. A focus on parietal cells as a renewing cell population. World J Gastroenterol 2010; 16(5): 538-46.

15. Enayetullah M. Gross and histomorphological study of the thyroid and parathyroid glands in Bangladeshi people. [Thesis]. Dhaka: University of Dhaka; 1996.
16. Helander HF, Leth R, Olbe L. Stereological investigations on human gastric mucosa: I. Normal oxyntic mucosa. Anat Rec 1986; 216: 373-80.

17. Mercer DW, Robinson EK. Stomach. In: Townsend CM Jr, Beauchamp RD, Evers BM, Mattox KL. eds. Sabiston textbook of surgery: the biological basis of modern surgical practice. $18^{\text {th }}$ ed. New Delhi: Saunders Elsevier; 2008: p.1227.

18. Kumar V, Abbas AK, Fausto N, Aster JC. eds. Robbins and Cotran pathologic basis of disease. $8^{\text {th }}$ ed. New Delhi: Saunders; 2010: p.774.

19. Kopic S, Murek M, Geibel JP. Revisiting the parietal cell. Am J Physiol 2010; 298(1): C1-C10.

20. Ito S. Functional gastric morphology. In: Johnson LR. ed. Physiology of the gastrointestinal tract. $2^{\text {nd }}$ ed. New York: Raven Press; 1987: p.817.

21. Rohrer GV, Scott JR, Joel W, Wolf S. The fine structure of human gastric parietal cells. Digestive Dis Sci 1965; 10(1): 13-21.

22. Gartner LP, Hiatt JL. Color textbook of histology. $3^{\text {rd }}$ ed. Philadelphia: Saunders Elsevier; 2007: p.389. 